\title{
Evaluation of the Emissions from the Pyrolytic Treatment of PAHs Soil Contaminated Soil
}

\author{
Diana Mariana Cocârță ${ }^{1}$, Ana Maria Velcea ${ }^{1}$, Constantin Stan ${ }^{1}$, Adrian Alexandru Badea ${ }^{2}$ \\ ${ }^{1}$ Department of Energy Production and Use, Faculty of Power Engineering, University POLITEHNICA of Bucharest \\ Splaiul Independentei no 313, Bucharest, Romania \\ diana.cocarta@upb.ro; ana.velcea@yahoo.com; stan.constantin@yahoo.com \\ ${ }^{2}$ Academy of Romanian Scientists \\ Splaiul Independentei no 54, Bucharest, Romania \\ adrian.badea@energ.pub.ro
}

\begin{abstract}
The present paper examines the emissions of polycyclic aromatic hydrocarbons (PAHs) resulted from the thermal treatment through pyrolysis process of contaminated soil with petroleum products. Specifically, across the experimental work, the process temperature influence on PAHs and Phenanthrene emissions and remediation degree during the thermal treatment were investigated. The pyrolytic treatment of the contaminated soils was performed at different temperatures and time: $400^{\circ} \mathrm{C}$ for $60 \mathrm{~min} ; 600^{\circ} \mathrm{C}$ for $30 \mathrm{~min}$ and $800^{\circ} \mathrm{C}$ for $30 \mathrm{~min}$. The obtained results revealed that non-oxidative atmosphere at temperatures between $400^{\circ} \mathrm{C}$ and $800^{\circ} \mathrm{C}$ reduced $\mathrm{PAHs}$ and Phenanthrene to below regulatory standards. More than that, it was evidenced that, when the initial concentration of the contaminants in soil is not too high (content of PAHs in soil was $26.811 \mathrm{mg} / \mathrm{kg}_{\text {d.w. }}$ respect to $25 \mathrm{mg} / \mathrm{kg}_{\text {d.w. }}$, while for Phenanthrene initial concentration in soil was $19.264 \mathrm{mg} / \mathrm{kg}_{\text {d.w. }}$. respect to $5 \mathrm{mg} / \mathrm{kg}_{\text {d.w. }}$ from the regulation in force) even a low-temperature of $400^{\circ} \mathrm{C}$ for the pyrolysis process ensure an efficiency in removing PAHs and Phenanthrene higher than $99 \%$. It was evidenced that, increasing the process temperature with $200^{\circ} \mathrm{C}$ and respectively with $400^{\circ} \mathrm{C}$, respect to the selected pyrolysis conditions as appropriate $\left(400^{\circ} \mathrm{C}\right.$ for 60 minutes), has no relevance in terms of reducing contaminants from the contaminated soil. This is an important advantage considering that lower temperatures are requiring lower energy costs and soil fertility is not affected as in case of soil incineration or other thermal treatment methods.
\end{abstract}

Keywords: Soil pollution, Remediation, Polycyclic aromatic hydrocarbons, Pyrolysis.

\section{Introduction}

Worldwide, contamination of soils with petroleum products pose significant risks both for environment and human health. In Romania soil contamination was estimated at 201 contaminated and 1183 potentially contaminated sites. At national level, the main economic sectors with important impact on soil quality are mining and metallurgical industries, chemical industry, oil industry and old pesticide deposits [1].

Contamination of soil with petroleum products is a major environmental problem because of pollution with dangerous pollutants as heavy metals ( $\mathrm{Zn}, \mathrm{Fe}, \mathrm{Mn}, \mathrm{Pb}, \mathrm{Ni}, \mathrm{Cr}, \mathrm{Cu}, \mathrm{Cd}, \mathrm{Hg}, \mathrm{As})$, polycyclic aromatic hydrocarbons (PAHs), total petroleum hydrocarbons (TPHs) and polychlorinated-biphenyls (PCBs) [2] [3].

For the remediation of contaminated soils, many methods such as thermal, chemical, microbial or physicochemical procedures are used. These methods can be used alone or in combination, on site or off-site application [4] [5].

Compared to other soil remediation thermal methods as incineration and thermal desorption, the pyrolysis method has the advantage of obtaining a good quality of the remaining soil, which allows using it for different purposes [6] [7].

In this context, the current paper presents the obtained results by using the pyrolysis method for remediation of soil contaminated with PAHs by petroleum hydrocarbon release. The research objective was to illustrate the remediation degree concerning the removal of PAHs and Phenanthrene from contaminated soils at different operating temperatures, as well as associated retention times of the material (contaminated soil) in the reactor. 


\section{Material and methods}

\subsection{Soil sampling and main characteristics}

Soil samples were collected from a contaminated site (of about $1000 \mathrm{~m}^{2}$ ) accidentally polluted with crude oil. We selected soil sampling following the simple random sampling design [8]. So, 5 samples were chosen (according to the regulation in force [9]) and mixed together to form a unique and homogenous sample. Soil characterization was performed according to current analytical standards as illustrated in Table 1. We performed elemental analysis of TPHs content in soil (Table 2) using HPLC model Agilent 1200 with Fluorescence Detector, from Agilent Technologies (California, USA) and having as support the analytical procedures from the Romanian standard SR ISO 13877:1999 [10]. Table 2 indicates also the references values concerning the allowed concentrations of the contaminants in soil according to the national regulation in force [11].

Table 1: Physicochemical properties of raw soil.

\begin{tabular}{|c|c|c|c|}
\hline Parameter & Units & Determined values & Methods \\
\hline $\mathrm{pH}$ (aqueous extract 1:5) & unit. $\mathrm{pH}$ & 7.84 & SR ISO 10390:2015 \\
\hline Potassium $-\mathrm{K}$ (aqueous extract 1:5) & $\mathrm{mg} / \mathrm{kg}$ d.w. & 17.11 & ISO 9964-1:1993 \\
\hline Phosphorus - P (aqueous extract 1:5) & $\mathrm{mg} / \mathrm{kg}$ d.w. & 13.22 & STAS $7184 / 7-87$ \\
\hline Total nitrogen & $\mathrm{mg} / \mathrm{kg}$ d.w. & 1.73 & SR ISO 11261:2000 \\
\hline $\mathrm{K}$ & $\mathrm{mg} / \mathrm{kg}$ d.w. & 6302.85 & EPA 7000A:1992 \\
\hline Total phosphorus & $\mathrm{mg} / \mathrm{kg}$ d.w. & 290.16 & STAS 7184/14-79 \\
\hline Total organic carbon & $\%$ d.w. & 12.52 & \multirow{2}{*}{ STAS 7184/21-82 } \\
\hline Humus & $\%$ d.w. & 21.59 & \\
\hline Chlorides (aqueous extract 1:5) & $\mathrm{mg} / \mathrm{kg} \mathrm{d.w.}$ & 336.85 & STAS 7184/7-87 \\
\hline
\end{tabular}

Table 2: PAH content of raw soil.

\begin{tabular}{|l|l|c|c|c|c|}
\hline $\begin{array}{c}\text { Parameter } \\
\text { analyzed }\end{array}$ & \multicolumn{1}{|c|}{ Units } & $\begin{array}{c}\text { Determined } \\
\text { values }\end{array}$ & $\begin{array}{c}\text { Normal } \\
\text { value }\end{array}$ & $\begin{array}{c}\text { Alert } \\
\text { thresholds }\end{array}$ & $\begin{array}{c}\text { Intervention } \\
\text { thresholds }\end{array}$ \\
\hline$\Sigma$ PAH* & $\mathrm{mg} / \mathrm{kg} \mathrm{d.w.}$ & 26.811 & $<0.1$ & 25 & 150 \\
\hline Naphthalene & $\mathrm{mg} / \mathrm{kg} \mathrm{d.w.}$ & 0.467 & 0.02 & 5 & 50 \\
\hline Acenaphthene & $\mathrm{mg} / \mathrm{kg} \mathrm{d.w.}$ & 0.063 & - & - & - \\
\hline Fluorene & $\mathrm{mg} / \mathrm{kg} \mathrm{d.w.}$ & 1.522 & - & - & - \\
\hline Phenanthrene & $\mathrm{mg} / \mathrm{kg} \mathrm{d.w.}$ & 19.264 & $<0.05$ & 5 & 50 \\
\hline Anthracene & $\mathrm{mg} / \mathrm{kg} \mathrm{d.w.}$ & 0.009 & $<0.05$ & 10 & 100 \\
\hline Fluoranthene & $\mathrm{mg} / \mathrm{kg} \mathrm{d.w.}$ & 0.427 & $<0.05$ & 10 & 100 \\
\hline Pyrene & $\mathrm{mg} / \mathrm{kg} \mathrm{d.w.}$ & 0.898 & $<0.05$ & 10 & 100 \\
\hline $\begin{array}{l}\text { Benzo-a- } \\
\text { anthracene }\end{array}$ & $\mathrm{mg} / \mathrm{kg} \mathrm{d.w.}$ & 2.026 & $<0.02$ & 5 & 50 \\
\hline Chrysene & $\mathrm{mg} / \mathrm{kg} \mathrm{d.w.}$ & 0.286 & $<0.02$ & 5 & 50 \\
\hline $\begin{array}{l}\text { Benzo-b- } \\
\text { fluoranthene }\end{array}$ & $\mathrm{mg} / \mathrm{kg} \mathrm{d.w.}$ & 0.284 & $<0.02$ & 5 & 50 \\
\hline $\begin{array}{l}\text { Benzo-k- } \\
\text { fluoranthene }\end{array}$ & $\mathrm{mg} / \mathrm{kg} \mathrm{d.w.}$ & 0.064 & $<0.02$ & 5 & 50 \\
\hline $\begin{array}{l}\text { Benzo-a- } \\
\text { pyrene }\end{array}$ & $\mathrm{mg} / \mathrm{kg}$ d.w. & 0.211 & $<0.02$ & 5 & 50 \\
\hline $\begin{array}{l}\text { Dibenzo-a,h- } \\
\text { anthracene }\end{array}$ & $\mathrm{mg} / \mathrm{kg} \mathrm{d.w.}$ & 0.135 & - & - & - \\
\hline
\end{tabular}




\begin{tabular}{|l|l|c|c|c|c|}
\hline $\begin{array}{c}\text { Parameter } \\
\text { analyzed }\end{array}$ & Units & $\begin{array}{c}\text { Determined } \\
\text { values }\end{array}$ & $\begin{array}{c}\text { Normal } \\
\text { value }\end{array}$ & $\begin{array}{c}\text { Alert } \\
\text { thresholds }\end{array}$ & $\begin{array}{c}\text { Intervention } \\
\text { thresholds }\end{array}$ \\
\hline $\begin{array}{l}\text { Benzo-ghi- } \\
\text { perylene }\end{array}$ & $\mathrm{mg} / \mathrm{kg} \mathrm{d.w.}$ & 0.054 & $<0.05$ & 10 & 100 \\
\hline $\begin{array}{l}\text { Indeno-1,2,3- } \\
\text { cd-pyrene }\end{array}$ & $\mathrm{mg} / \mathrm{kg} \mathrm{d.w.}$ & 0.100 & $<0.02$ & 5 & 50 \\
\hline
\end{tabular}

$* \Sigma$ PAHs - represents the concentration of the 16 EPA-designed priority PAHs

\subsection{Experimental framework}

The thermal treatment of the contaminated soil was performed using a laboratory tubular batch reactor designed and operated within Renewable Energy Sources Laboratory from University POLYTECHNIC of Bucharest (NABERTHERM, type RO 60/750/13). The pyrolysis reactor is working in a discontinuously mode and the process temperature can be adjusted between $20-1300{ }^{\circ} \mathrm{C}$. The refractory steel tube is $60 \mathrm{~mm}$ in diameter with a total length of $750 \mathrm{~mm}$ and the isothermal active zone of the crucible is $300 \mathrm{~mm}$ (zone where the material/soil sample is placed) [12]. The main components of the tubular batch reactor are illustrated in Figure 1.

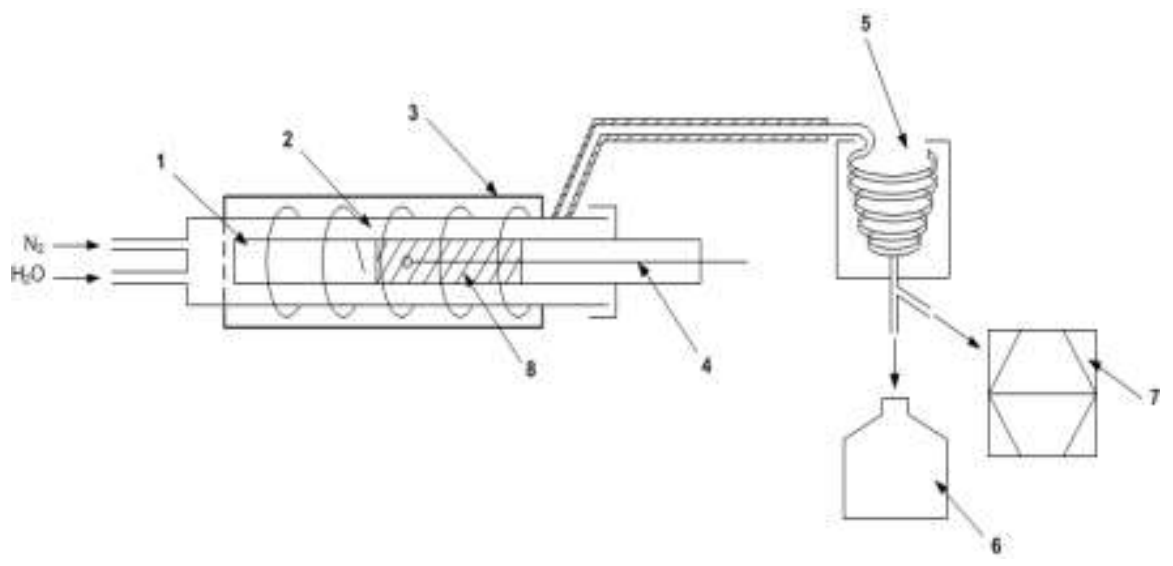

Fig. 1: Tubular batch reactor [12] [13] [14].

1. Refractory steel crucible; 2. Refractory steel tube; 3. Electrically heated chamber; 4. Thermocouple; 5. Condensable hydrocarbons fraction separation system; 6. Collector; 7. Gas analysis system; 8. Sample.

The process parameters used for the pyrolytic treatment of the contaminated soil are presented in table 3 .

Table 3: Process parameters of the pyrolytic treatment.

\begin{tabular}{|c|l|c|}
\hline Treatment type & Temperature & Time \\
\hline Low - Temperature pyrolysis & $400^{\circ} \mathrm{C}$ & $60 \mathrm{~min}$ \\
\hline Low - Temperature pyrolysis & $600^{\circ} \mathrm{C}$ & $30 \mathrm{~min}$ \\
\hline Mid - Temperature pyrolysis & $800^{\circ} \mathrm{C}$ & $30 \mathrm{~min}$ \\
\hline
\end{tabular}

During the experimental work treated soil samples and emission from the thermal treatment were investigated. In order to quantify concentrations of PAHs from emissions from the thermal process, solid and gas phase samples were collected using an isokinetic automatic portable sampling system ISOSTACK Basic HV was used (TCR Tecora). The sampling system has been described in previous works [7] [15]. The working principle of the analytical device is based on isokinetic sampling conditions of a gas volume and deposition of toxic compounds. In this way, the gas phase of the contaminants was sampled on the PolyUrethane Foam Sampler (PUF) and while the solid phase was collected on a quartz filter element, according to EN1948 [16]. Subsequently, the collected samples were sent to a specialised and accredited laboratory for quantitative determinations of PAHs. 


\section{Results and discussions}

From Table 2, where the characterisation of the contaminated soil is evidenced comparing with the allowed concentrations level according to the regulation in force, could be noticed that for $\Sigma$ PAHs and Phenanthrene compounds the concentration level in soil is higher than the established thresholds. Concerning $\mathrm{P}$ AHs, the concentration in soil is with almost $2 \mathrm{mg} / \mathrm{kg}_{\text {d.w }}$ higher than the acceptable limit of $25 \mathrm{mg} / \mathrm{kg}_{\text {d.w }}$, while for Phenanthrene, the determined concentration is almost 4 times higher than the established limit: $19.264 \mathrm{mg} / \mathrm{kg}_{\text {d.w }}$, compared with $5 \mathrm{mg} / \mathrm{kg}_{\text {d.w }}$. With regard to the other investigated PAHs, concentrations of chemicals as Naphthalene, Benzo-a-anthracene, Chrysene, Benzo-b-fluoranthene, Benzo-k-fluoranthene and Benzo-a-pyrene are exceeding only the normal values (Table 2). According to the regulation in force, special measures are required when alert or intervention thresholds are surpassed at least for one contaminant. As consequence, for the evaluation of the achieved results, the attention was mainly focused on Phenanthrene and $\Sigma$ PAHs.

The obtained results after soil pyrolysis at different temperatures $\left(400^{\circ} \mathrm{C}, 600^{\circ} \mathrm{C}\right.$ and $\left.800^{\circ} \mathrm{C}\right)$ indicates that the PAHs removal from soil reaches values higher than $98 \%$, exception Naphthalene for which the remediation degree was around 95\%. On the other hand, as it was observed also by other authors [6], the removal of PAHs from the contaminated soils (or the conversion of the contaminated soil in "char") through the pyrolysis process starts between $300^{\circ} \mathrm{C}$ and $350^{\circ} \mathrm{C}$, proceeds rapidly in the $400-450^{\circ} \mathrm{C}$ range and is usually complete before $500^{\circ} \mathrm{C}$. This is sustained also by the results achieved through the illustrated experimental work: initial concentration of $\Sigma \mathrm{PAHs}$ in soil is $26.811 \mathrm{mg} / \mathrm{kg}_{\mathrm{d} . w}$, after the pyrolytic treatment at $400{ }^{\circ} \mathrm{C}$ for 60 minutes is decreasing to $0.046 \mathrm{mg} / \mathrm{kg}_{\text {d.w. }}$ (the remediation degree is higher than $99 \%$ ), while process temperatures equal with $600^{\circ} \mathrm{C}$ and $800^{\circ} \mathrm{C}$ are not having important influence on the concentration of the contaminants in treated soil ( $\mathrm{P}$ PAHs concentration in soil $0.043 \mathrm{mg} / \mathrm{kg}_{\text {d.w. }}$. respectively, $0,040 \mathrm{mg} / \mathrm{kg}_{\text {d.w. }}$ ). An overview on the behavior of compounds according to the process temperature and retention time is illustrated in Figure 2 (for PAHs for which initially concentration in soil exceeded the normal values) and Figure 3 a) (for $\Sigma$ PAHs). It was chosen the graphical representation only for the contaminants for which concentration in soil after the pyrolytic treatment is higher than $0.001 \mathrm{mg} / \mathrm{kg}_{\text {d.w. }}$.

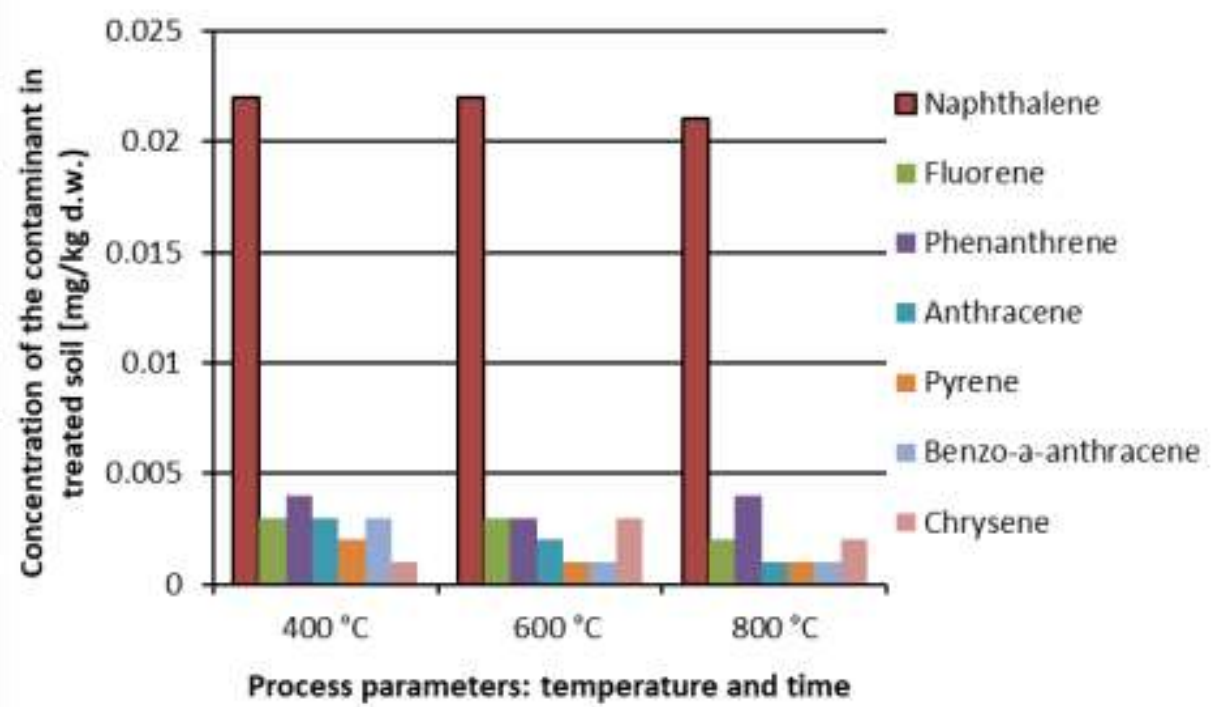

Fig. 2: Concentration of PAHs in treated soil after pyrolysis at different temperatures.

Even if there are different publications on pyrolysis treatment on hydrocarbon contaminated soils, just limited information is provided on emissions that are resulting when the pyrolytic treatment is applied for removal of hydrocarbons (specifically PAHs) from soil. For this reason, the experimental work followed also to determine the emissions of PAHs during the thermal treatment of the contaminated soil. Figure 3 and Figure 4 are illustrating concentrations of $\mathrm{PPAHs}$ and Phenanthrene in soil and emissions (simultaneously) for different process temperatures. 


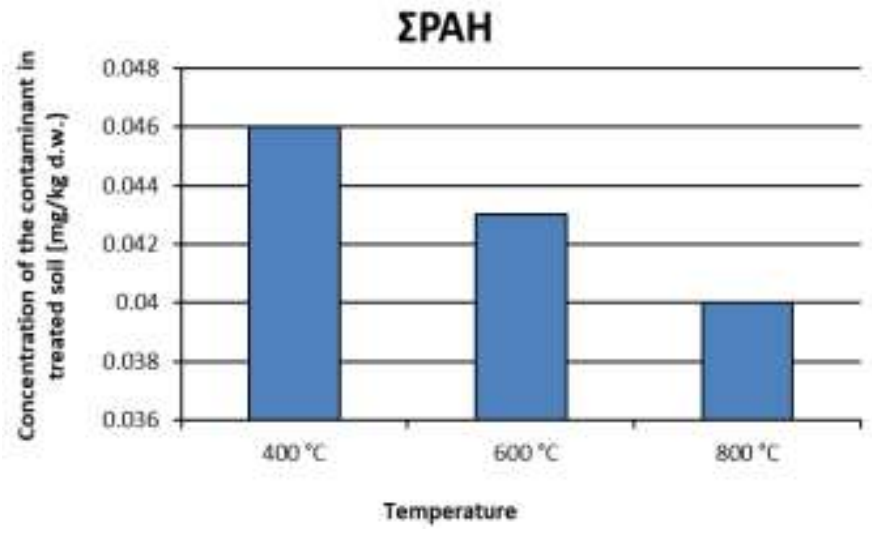

a) $\Sigma$ PAHs in treated soil at different temperatures
¿PAH

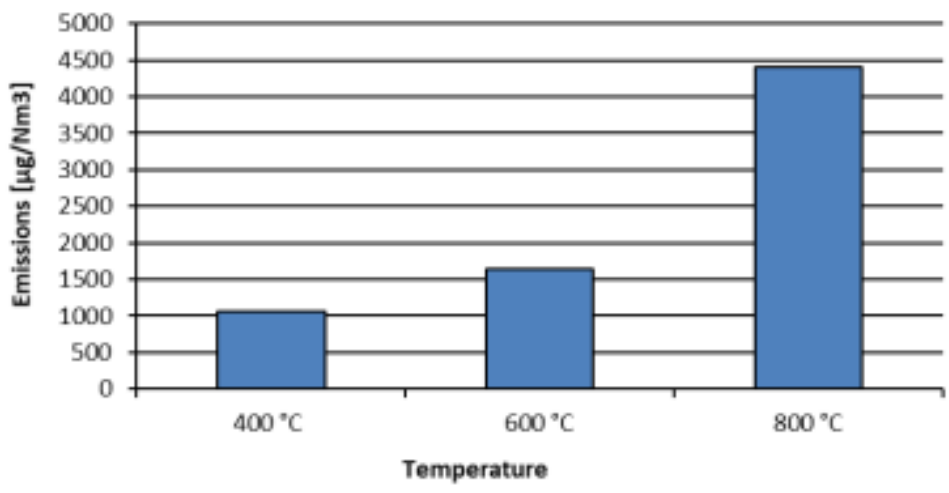

b) $\Sigma$ PAHs emissions at different temperatures

Fig. 3: Concentration of $\Sigma$ PAHs in treated soil and $\Sigma$ PAHs emissions during the pyrolysis treatment.

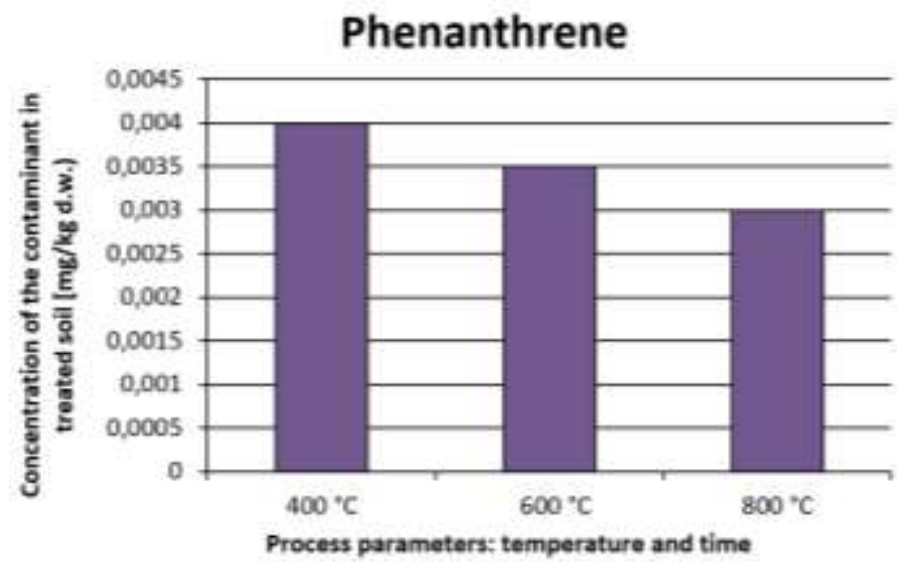

a) $\Sigma$ PAHs in treated soil at different temperatures
Phenanthrene

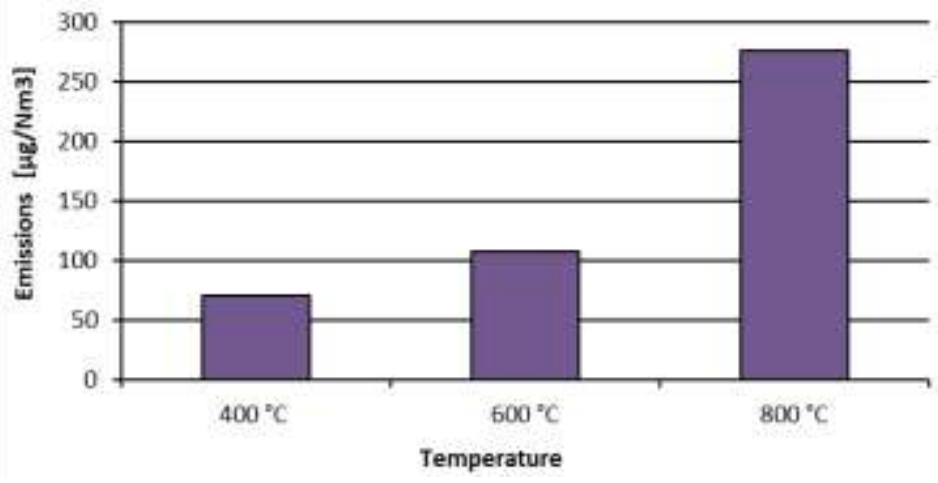

b) $\Sigma$ PAHs emissions at different temperatures

Fig. 4: Concentration of Phenanthrene in treated soil and Phenanthrene emissions during the pyrolysis treatment.

The figures above indicate that, increasing process temperature, has as consequence the fact that the concentrations of the contaminants in treated soil are decreasing (over 99\%), while the emissions of $\Sigma$ PAHs and Phenanthrene are increasing. The obtained results concerning the concentrations of $\Sigma \mathrm{PAHs}$, in treated soil at $400^{\circ} \mathrm{C}$ for 60 minutes indicates that the selected pyrolysis conditions were appropriate. The same trend is followed also in case of every single investigated compound. Increasing the process temperature with $200^{\circ} \mathrm{C}$ has no relevance in terms of reducing contaminants from the contaminated soil and additionally requires more energy consumption, reducing in the same time the fertility of the treated soil, as demonstrated by other authors [6]). So, higher process temperature in the pyrolysis process showed that high emissions factors of $\Sigma$ PAHs can be obtained: $1059.71 \mu \mathrm{g} / \mathrm{Nm}^{3}$ at $400^{\circ} \mathrm{C}, 1646.75 \mu \mathrm{g} / \mathrm{Nm}^{3}$ at $600^{\circ} \mathrm{C}$ and $4398.94 \mu \mathrm{g} / \mathrm{Nm}^{3}$ at $800^{\circ} \mathrm{C}$. Between the studied elements were highlighted especially: Fluorene $\left(567.16 \mu \mathrm{g} / \mathrm{Nm}^{3}\right.$ at $400^{\circ} \mathrm{C} ; 882.23 \mu \mathrm{g} / \mathrm{Nm}^{3}$ at $600^{\circ} \mathrm{C}$ and $1473.42 \mu \mathrm{g} / \mathrm{Nm}^{3}$ at $\left.800^{\circ} \mathrm{C}\right)$, Benzo-a-anthracene $\left(151.48 \mu \mathrm{g} / \mathrm{Nm}^{3}\right.$ at $400^{\circ} \mathrm{C} ; 175.86 \mu \mathrm{g} / \mathrm{Nm}^{3}$ at $600^{\circ} \mathrm{C}$ and 797.56 $\mu \mathrm{g} / \mathrm{Nm}^{3}$ at $\left.800^{\circ} \mathrm{C}\right)$ and Phenanthrene $\left(70.34 \mu \mathrm{g} / \mathrm{Nm}^{3}\right.$ at $400^{\circ} \mathrm{C} ; 107.05 \mu \mathrm{g} / \mathrm{Nm}^{3}$ at $600^{\circ} \mathrm{C}$ and $275.77 \mu \mathrm{g} / \mathrm{Nm}^{3}$ at $\left.800^{\circ} \mathrm{C}\right)$. 


\section{Conclusion}

The pyrolytic process used as treatment method of the contaminates sites with crude oil requires attention also from the environmental point of view. It must be avoided that the compounds in the treated soil are subsequently found in the emissions generated by the application of the remediation method.

The present research was mainly focused on the emissions of PAHs resulted from the pyrolysis treatment of contaminated soil with hydrocarbons. In the pyrolysis process $\left(400^{\circ} \mathrm{C}\right)$ it was shown that concentration of PAHs in soil are decreasing significantly being maintained in the same time the soil fertility Increasing the temperature of the process does not provide a significantly lower level of contaminants in the soil, but it influences in the sense of increasing the level of emissions of contaminants resulting from the thermal treatment of the polluted soil.

These kinds of information are very useful for the decision makers who must to identify opportunities to increase process sustainability together with the efficiency of removing contaminants as PAHs from contaminated soils.

\section{Acknowledgements}

This work was supported under the GNaC 2018 ARUT / ELBIOCOM project, ctr. no 14/15.10.2018 financed by University POLITEHNICA of Bucharest, Romania and under contract no 23/02.05.2019 financed by Academy of Romanian Scientists.

\section{References}

[1] Government Decision no. 683 from August 19, 2015 for approval of the National Strategy and the National Plan for the management of contaminated sites in Romania, published in Official Monitor no. 656/ August 31, 2015.

[2] I. A. Istrate, Gh. Voicu, E. C. Rada, "Hydrocarbons soil pollution in Romania: issues and solutions," Fresenius Environmental Bulletin, vol. 25, no. 8, pp. 3243-3250, 2016.

[3] E. C. Rada, I.A. Istrate, V. Panaitescu, M. Ragazzi, T.M. Cirlioru, T. Apostol, "A comparison between different scenarios of Romanian municipal solid waste treatment before landfilling," Environmental Engineering and Management Journal, vol. 9, no. 4, pp. 589-596, 2010.

[4] D. Rahner, G. Ludwig, J. Rohrs, "Electrochemically induced reactions in soils - a new approach to the in situ remediation of contaminated soils. Part1," Electrochimica Acta, vol. 47, pp. 1395 - 1403, 2002.

[5] E. C. Rada, Thermochemical waste treatment: combustion, gasification, and other methodologies. Apple Academic Press, 2016.

[6] J. E. Vidonish, K. Zygourakis, C. A. Masiello, X. Gao, J. Mathieu, P. J. J. Alvarez, "Pyrolytic Treatment and Fertility Enhancement of Soils Contaminated with Heavy Hydrocarbons," Environmental Science and Technology, no. 50, pp. 2498-2506, 2016.

[7] D. M. Cocârţă, G. E. Dumitran, M. A. Diminescu, L. Vuţă, "Removal efficiency and gas/particle partitioning of PCBs emissions from thermal treatment of PCBs contaminated soil," Journal of Environmental Protection and Ecology, vol. 17, no. 3, pp. 970-977, 2016.

[8] US EPA, "Guidance on Choosing a Sampling Design for Environmental Data Collection for Use in Developing a Quality Assurance Project Plan,” EPA QA/G-5S, EPA/240/R-02/005, 2002.

[9] Ministry Order no. 184 from September 21, 1997 for approval of the environmental balance procedure, published in Official Monitor no. 303/ November 6, 1997.

[10] SR ISO 13877:1999 "Soil quality. Determination of polynuclear aromatic hydrocarbons. Method using highperformance liquid chromatography," 1999.

[11] Ministry Order no. 756 from November 3, 1997 for approval of Regulation concerning environmental pollution assessment, published in Official Monitor no. 303/ November 6, 1997.

[12] C. Stan, "Energy recovery from industrial feather waste by gasification," Journal of Clean Energy Technologies, vol. 6, no. 6, 2018.

[13] C. Streche, "Experimental researches regarding the treatment of organic polluted soils, by the application of thermal and electric treatments," Ph. D. dissertation, Department of Energy Production and Use, Faculty of Power Engineering, University POLITEHNICA of Bucharest, Romania, 2009.

[14] D. M. Cocârţă, C. Streche, Soil and Air Quality Monitoring Techniques, Laboratory Guidance and Practical Applications. Politehnica Press, 2017. 
[15] D.M. Cocârţă, A. Badea, G. Antonacci, A. Cemin, "Two case studies of particulate matter emissions from power plants," Environmental Engineering and Management Journal, vol. 10, no. 5, pp. 615 - 619, 2011.

[16] EN EUROPEAN STANDARD EN-1948:1996 p. 1-3 ICS 13.040.40 "Stationary source emissions - Determination of the mass concentration of PCDDs/PCDFs. Part 1: Sampling. Part 2: Extraction and clean-up. Part 3: Identification and quantification," 1996. 